Article

\title{
Surveillance of Coxiella burnetii Shedding in Three Naturally Infected Dairy Goat Herds after Vaccination, Focusing on Bulk Tank Milk and Dust Swabs
}

\author{
Benjamin U. Bauer ${ }^{1, *(D)}$, Clara Schoneberg ${ }^{2}$, T. Louise Herms ${ }^{3}$, Martin Runge ${ }^{3}$ and Martin Ganter ${ }^{1}$ (D) \\ 1 Clinic for Swine and Small Ruminants, Forensic Medicine and Ambulatory Service, University of Veterinary \\ Medicine Hannover, Foundation, Bischofsholer Damm 15, 30173 Hannover, Germany; \\ martin.ganter@tiho-hannover.de \\ 2 Department of Biometry, Epidemiology and Information Processing, WHO Collaborating Centre for Research \\ and Training for Health in the Human-Animal-Environment Interface, University of Veterinary Medicine \\ Hannover, Foundation, Bünteweg 2, 30559 Hannover, Germany; clara.schoneberg@tiho-hannover.de \\ 3 Lower Saxony State Office for Consumer Protection and Food Safety (LAVES), Food and Veterinary Institute \\ Braunschweig/Hannover, Eintrachtweg 17, 30173 Hannover, Germany; \\ louise.pruefer@laves.niedersachsen.de (T.L.H.); martin.runge@laves.niedersachsen.de (M.R.) \\ * Correspondence: benjamin.bauer@tiho-hannover.de
}

check for updates

Citation: Bauer, B.U.; Schoneberg, C.; Herms, T.L.; Runge, M.; Ganter, M. Surveillance of Coxiella burnetii Shedding in Three Naturally Infected Dairy Goat Herds after Vaccination, Focusing on Bulk Tank Milk and Dust Swabs. Vet. Sci. 2022, 9, 102. https://doi.org/10.3390/ vetsci9030102

Academic Editor: Patrick Butaye

Received: 12 January 2022

Accepted: 23 February 2022

Published: 24 February 2022

Publisher's Note: MDPI stays neutral with regard to jurisdictional claims in published maps and institutional affiliations.

Copyright: (C) 2022 by the authors. Licensee MDPI, Basel, Switzerland. This article is an open access article distributed under the terms and conditions of the Creative Commons Attribution (CC BY) license (https:// creativecommons.org/licenses/by/ $4.0 /)$.

\begin{abstract}
Q$ fever outbreaks on three dairy goat farms $(\mathrm{A}-\mathrm{C})$ were monitored after the animals had been vaccinated with an inactivated Coxiella burnetii phase I vaccine. The antibody response was measured before vaccination by serum samples with two C. burnetii phase-specific ELISAs to characterize the disease status. Shedding was determined by vaginal swabs during three kidding seasons and monthly bulk tank milk (BTM) samples. Dust swabs from one windowsill of each barn and from the milking parlors were collected monthly to evaluate the indoor exposure. These samples were analyzed by qPCR. The phase-specific serology revealed an acute $\mathrm{Q}$ fever infection in herd A, whereas herds $\mathrm{B}$ and $\mathrm{C}$ had an ongoing and past infection, respectively. In all three herds, vaginal shedders were present during three kidding seasons. In total, $50 \%, 69 \%$, and $15 \%$ of all collected BTM samples were C. burnetii positive in herds A, B, and C, respectively. Barn dust contained C. burnetii DNA in $71 \%, 45 \%$, and $50 \%$ of examined swabs collected from farms A, B, and C, respectively. The largest number of $C$. burnetii positive samples was obtained from the milking parlor (A: $91 \%, B: 72 \%$, $\mathrm{C}: 73 \%$ ), indicating a high risk for humans to acquire $\mathrm{Q}$ fever during milking activity.
\end{abstract}

Keywords: bulk tank milk; dust swab; goat; longitudinal study; milking parlor; phase-specific serology; One Health; Q fever; vaccination; zoonosis

\section{Introduction}

$\mathrm{Q}$ fever is a zoonotic disease caused by the obligate intracellular bacterium Coxiella burnetii. The pathogen has a high tenacity, with resistance to desiccation, heat, UV light, and numerous disinfectants [1,2]. The main reservoirs of the pathogen are cattle, sheep, and goats, which shed the bacteria mainly through birth products during abortion or normal parturition, but also through feces and milk $[3,4]$. Reproductive disorders are known in goats, with high abortion rates up to $90 \%$, stillbirth, and weak kids $[3,5,6]$. The impact of $C$. burnetii on cattle health is still unknown and under debate [7], whereas sheep seem to be less affected, with low abortion rates of up to $5 \%$ [8].

Humans become easily infected with $C$. burnetii when inhaling contaminated aerosols and dust. The median infectious dose (ID50) was estimated at 1.5 bacteria and indicates the high infectivity of C. burnetii via aerosols [9]. In the Netherlands, drifting particulate matter from C. burnetii positive dairy goat farms led to the world's largest $Q$ fever epidemic, with more than 4000 reported human cases and an estimated number of about 40,000 infected individuals $[10,11]$. Furthermore, one 'super-spreading' ewe infected 299 visitors 
at a German farmers' market [12]. In addition to inhalation, the consumption of raw milk contaminated with C. burnetii is considered a sporadic route of transmission $[2,13]$. Approximately $40 \%$ of infected humans show flu-like symptoms, such as fever, pneumonia, and hepatitis [14]. In the long term, up to $20 \%$ of patients with acute $Q$ fever develop chronic fatigue syndrome [15], and affected patients with lesions of the cardio-vascular system suffer from endocarditis and vascular disease $[14,16]$. Seroprevalence among people within the European Union is highly diverse, and ranges from $1 \%$ in the general population, up to $83.8 \%$ in livestock veterinarians [17]. A C. burnetii seroprevalence of $3.1 \%$ was reported for humans in the United States [18]. In Australia, a seroprevalence of approximately 5\% was determined in the rural population and in people living in metropolitan areas [19]. These results show that the risk of contracting $Q$ fever is independent from the place of residence.

A particular characteristic of $C$. burnetii is its antigenic phase variation, leading to phase $\mathrm{I}(\mathrm{PhI})$ and phase II (PhII), which correlates with lipopolysaccharide changes [20,21]. These features are used for phase-specific serology to investigate the infection dynamics in goat flocks. The rise in IgG PhII antibodies without the appearance of IgG PhI are interpreted as a recently acquired infection [22,23]. Equal levels of IgG PhI and PhII represent an ongoing infection and occur approximately nine weeks post-infection [22]. The exclusive presence of IgG PhI antibodies outlined an infection in the past [24]. Nevertheless, phase-specific serology is still not used for routine diagnostic in veterinary medicine, despite it being a valuable tool for studying infection dynamics in goat herds [25].

Without control measures, C. burnetii may circulate in goat herds for several years $[24,26,27]$. To prevent $Q$ fever outbreaks in livestock, an inactivated C. burnetii phase I vaccine has been licensed for cattle and goats in several European countries [28]. This vaccine significantly reduced abortion rates and excretion of the bacteria in naïve goats when given before mating [29]. Vaccination of pre-infected goats did not prevent vaginal shedding of $C$. burnetii, but reduced the amount of pathogen excretion and may also lower the number of shedders [30-32]. However, data about the long-term effect of $C$. burnetii phase I vaccine in naturally pre-infected goats on pathogen excretion are missing. Such information is essential for veterinary health care officials and other decision-makers to assess the risk of C. burnetii transmission to humans after a $\mathrm{Q}$ fever outbreak.

Bulk tank milk (BTM) samples have been successfully used to monitor the $Q$ fever status of dairy goat herds [33-35]. Analyzing caprine BTM samples for C. burnetii by PCR revealed a wide range of detection rates in several countries, such as $16 \%$ in Belgium [35], $32.9 \%$ in the Netherlands [34], 54\% in Poland [36], and 16.1\% in Iran [37]. However, this method is limited to dairy animals, and there is a growing interest to examine dust samples from animal facilities to detect $C$. burnetii on ruminant farms $[3,6,38-41]$. The pathogen was determined in dust samples for more than one year after an outbreak, but information about its infectiousness is limited [3,40]. Viable C. burnetii was detected in dust within two months after the last parturition [6]. Windowsills and fences were the preferred sampling locations $[3,38,41,42]$. Despite the high-risk during milking activity for farmers and farm workers [43,44], milking parlors have been rarely included in studies [45].

The present field investigation aimed to monitor three $Q$ fever outbreaks on dairy goat farms after an inactivated $C$. burnetii phase I vaccine was given. The shedding of $C$. burnetii was analyzed by vaginal swabs and monthly BTM samples over a period of three kidding seasons. Dust samples from one windowsill of each barn and from the milking parlors were included in the investigation to evaluate the intensity and duration of $C$. burnetii contamination of goat facilities. Our clinical long term observations supplement existing statistical models [26] and will contribute to future risk assessments of $Q$ fever outbreaks according to the One Health approach. 


\section{Materials and Methods}

\subsection{Herd History}

\subsubsection{Dairy Goat Herd A}

Dairy goat herd A was located in the German federal state of Schleswig-Holstein (northern Germany) and consisted of 360 does, which had suffered from endemic abortion with 24 aborting goats in January 2018. Later, several stillborn and weak kids were born up until the end of the kidding season in April 2018. Further details about kid losses during this period were not available. In early January 2018, an aborted fetus, including the placenta, was sent to the federal state laboratory of Schleswig-Holstein and examined for abortifacient agents, such as Brucella spp., Campylobacter fetus ssp. fetus, Chlamydia spp., C. burnetii, Listeria spp., and Salmonella spp. The only diagnosed pathogenic microorganism was C. burnetii (Cq 13; VetMAX ${ }^{\mathrm{TM}}$ C. burnetii Absolute Quant Kit, Thermo Fisher Scientific $\mathrm{GmbH}$, Dreieich, Germany). All goats were kept in one barn closed on all four sides with wooden walls. Ventilation occurred through the open front and back doors of the barn. The milking parlor was directly connected to the barn but separated by metal fences. The herd was managed semi-intensively under organic farming standards, with access to the pasture during the daytime annually from April until November. The whole dimension of the $Q$ fever outbreak was recently described in detail by the authors [44].

\subsubsection{Dairy Goat Herd B}

The animal stock of farm B consisted of 152 dairy goats and was located in the German federal state of North-Rhine Westphalia (western Germany). The kidding season took place from February to April 2018 and 20 goats showed reproductive disorders, such as abortion, stillborn, and weak kids at the end of the kidding season. Four aborted fetuses with placentas from two does were examined by the federal state laboratory of North Rhine-Westphalia to detect differential pathogens capable of causing abortion, such as Brucella spp., Campylobacter spp., Chlamydia spp., C. burnetii, bluetongue virus, pestivirus and Schmallenberg virus. The only detected abortifacient pathogen was C. burnetii $(\mathrm{Cq}$ 11-22; VetMAX ${ }^{\mathrm{TM}}$ C. burnetii Absolute Quant Kit, Thermo Fisher Scientific GmbH, Dreieich, Germany). The barn had three closed sides with wooden walls and one side with barn curtains. The goats had to enter and leave the milking parlor through a flap; therefore, the milking parlor was separated from the barn. On the organic farm, the goats were managed semi-intensively, and grazed during the daytime on pastures close to the barn from April until October each year.

\subsubsection{Dairy Goat Herd C}

Dairy goat herd C consisted of 85 dairy goats and was located in the German federal state of Bavaria (southern Germany). The main kidding season was in January 2018, but single animals still gave birth until March 2018. In February 2018, the first dead kids were born. In total, six goats gave birth to stillborn or weak kids. $\mathrm{Q}$ fever was considered as one cause of the disease, and vaginal swabs were collected from the twelve last kidding goats. The samples were analyzed by qPCR for the presence of $C$. burnetii, and all vaginal swabs tested positive (Cq 25-38; VetMAX ${ }^{\mathrm{TM}}$ C. burnetii Absolute Quant Kit, Thermo Fisher Scientific $\mathrm{GmbH}$, Dreieich, Germany) by the federal state laboratory of Lower Saxony (Germany). No other disease pathogens were investigated. Three sides of the barn were closed by barn curtains and the fourth side was a brick wall. The milking parlor was separated by a glass door from the barn. The intensively managed goats were mainly kept indoors, but had access to a concreted paddock, which was always accessible from April to November.

All three farmers $(\mathrm{A}-\mathrm{C})$ asked the Clinic for Swine and Small Ruminants at the University of Veterinary Medicine Hannover, Foundation, Hannover, Germany for help to combat the $\mathrm{Q}$ fever outbreak in their dairy goat herds. 


\subsection{Sample Collection}

On farm A, the kidding season was ongoing at the first visit in January 2018, whereas in flock B, only single goats were still pregnant at the first farm visit in April 2018. The main kidding season of herd $C$ had been completed two months earlier when the first measures had been implemented in April 2018.

\subsubsection{Blood Samples and Vaginal Swabs}

All aborting goats $(n=24)$ from herd A in January 2018 were included, and animals from herd B $(n=48)$ and C $(n=35)$ were randomly selected in April 2018 for serum samples to be taken from the Vena jugularis (KABE LABORTECHNIK GmbH, Nümbrecht-Elsenroth, Germany). From these goats, vaginal swabs were also collected at the first farm visit by the authors (B.U.B. and M.G). During the kidding season in 2019 and 2020, the farmers were instructed to carefully collect vaginal swabs from goats within $48 \mathrm{~h}$ after parturition. Due to the risk of single 'super-shedders' [3,27], as many vaginal swabs as possible were analyzed to describe the C. burnetii excretion to the greatest possible extent. Unfortunately, it was not possible to always sample the same goats during the study period because of difficulties in herd management on the farms.

\subsubsection{Bulk Tank Milk and Dust Swabs}

Bulk tank milk samples were taken monthly to monitor the shedding course at herd level during the entire study period (from first visit until September 2020). In addition, monthly dust samples from the milking parlors and from one windowsill of each barn were collected, as described previously [3]. Briefly, a dry swab (Sarstedt AG \& Co. KG, Nümbrecht, Germany) was rolled over the same windowsill from each barn covering one meter to collect dust. The same procedure was performed to collect dust from the milking parlor. The swab was rolled over the milk and vacuum pipeline (farm A) of the milking parlor on farm A or over one windowsill, which was located in the room of the milking parlors on farms B and C. The windowsills were chosen for sampling because the milk and vacuum pipelines were not easily accessible on farms $B$ and $C$. The sample locations within the barns and milking parlors were always the same on each farm. Neither cleaning nor disinfection was performed in any of the three barns and milking parlors during the entire study period.

\subsection{Vaccination Schedules and Breeding Management}

All goat herds were vaccinated for the first time with an inactivated C. burnetii phase I vaccine (Coxevac ${ }^{\circledR}$, Ceva, Libourne, France) in accordance with the manufacturer's instructions. Goats in herds B and C were annually revaccinated and the female progeny received their primary vaccination four weeks before mating. Animals in herd A had already been boosted in September 2018 before the breeding season started. This also included the primary vaccination of the female offspring from 2018. Since 2019, only the young offspring were vaccinated twice before breeding but the multiparous goats were left untreated on farm A. This modified vaccination schedule was performed due to financial reasons. In addition, all farmers were urged to remove aborted fetuses and afterbirth from the straw beddings as soon as possible and to store these materials in containers until disposal through rendering plants. The animal facilities on all three farms were neither cleaned nor disinfected during the entire study period.

Farms A and B continuously milked approximately half of the herd after the Q fever outbreak in 2018. The remaining does were mated and dried-off around six weeks before kidding. Farm $C$ bred the entire herd with a dry-off period of six weeks. Therefore, BTM samples were not always available from herd C.

An overview of the timing of blood/vaginal swab sampling, kidding seasons, and vaccination in all three dairy goat herds is provided in Supplementary Figure S1. 


\subsection{Laboratory Analysis}

Goat sera were examined with two phase-specific ELISAs (EUROIMMUN AG, Lübeck, Germany) in accordance with the manufacturer's instructions and this process has recently been described [46]. The test results were presented quantitatively in relative units (RU) determined by a standard curve. The manufacturer specified serum samples with RU $\geq 22$ as positive.

Coxiella burnetii-specific DNA fragments in the vaginal swabs were detected by amplification of the IS1111 elements with qPCR. Cycle Quantification (Cq) values $\leq 45$ were indicated as positive and $\mathrm{Cq}$ values $>45$ as negative values according to Frangoulidis and colleagues [47]. The BTM and dust samples were examined with a commercially available qPCR (LSI VetMAX ${ }^{\mathrm{TM}}$ C. burnetii Absolute Quant Kit, Thermo Fisher Scientific GmbH, Dreieich, Germany) targeting IS1111 as well. The manufacturer indicated Cq values $\leq 45$ as positive.

\subsection{Statistical Analyses}

Serum values were checked for normal distribution by the Shapiro-Wilk-Test, followed by a $t$-Test or Mann-Whitney-Test to compare the phase-specific IgG response within a goat herd. Results with $p<0.05$ were considered to be significant.

The vaginal swabs were evaluated using descriptive methods. Both the amount of $C$. burnetii DNA and the number of positive vaginal swabs were considered.

The statistical software SAS (SAS Institute Inc., Cary, NC, USA) was used for all calculations.

\section{Results}

\subsection{Serology}

In goat herd A, the median level of IgG PhII antibodies was significantly higher than the IgG PhI antibodies (Figure 1). The phase-specific antibodies did not significantly differ in herd B, and the IgG PhI median level was significantly higher than the IgG PhII level in herd $C$.

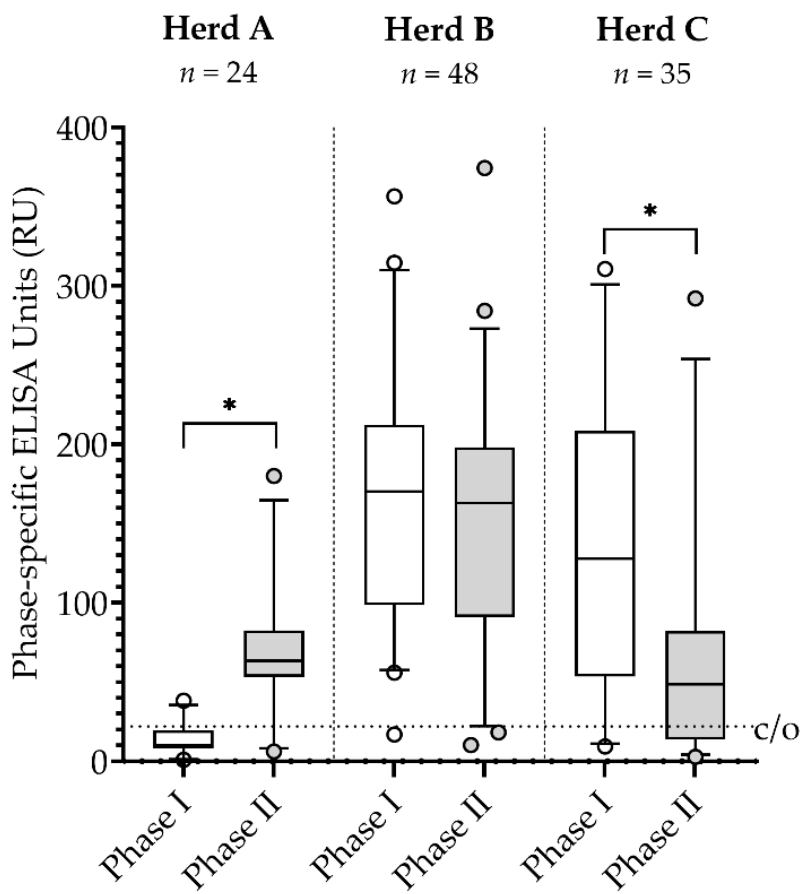

Figure 1. Median levels of IgG phase I and phase II Coxiella burnetii antibodies in three naturally infected dairy goat herds $(\mathrm{A}-\mathrm{C})$ at the start of the investigation in 2018. ${ }^{*} p<0.05 ; \mathrm{c} / \mathrm{o}=$ ELISA cut-off. 


\subsection{Vaginal Swabs}

All 24 examined goats from herd A shed C. burnetii in 2018, and half of the vaginal swabs contained large amounts of $C$. burnetii DNA $(\mathrm{Cq} \leq 20)$. At the subsequent kidding seasons, goats still shed small quantities $(\mathrm{Cq} \geq 33)$ of $C$. burnetii.

In herd B, all vaginal swabs tested C. burnetii positive at the initial sampling date $(\mathrm{Cq} \leq 33)$. In 2019 and 2020, the number of vaginal shedders decreased, and vaginal swabs contained small amounts of $C$. burnetii DNA $(\mathrm{Cq} \geq 37)$.

In 2018, 25 of 35 goats shed small amounts $(\mathrm{Cq} \geq 34)$ of $C$. burnetii through the vaginal route in herd C. During the following kidding seasons, fewer does excreted small quantities of C. burnetii $(\mathrm{Cq} \geq 36)$.

Details of the number of vaginal shedders and C. burnetii DNA amount (Cq-values) on vaginal swabs are shown in Figure 2.

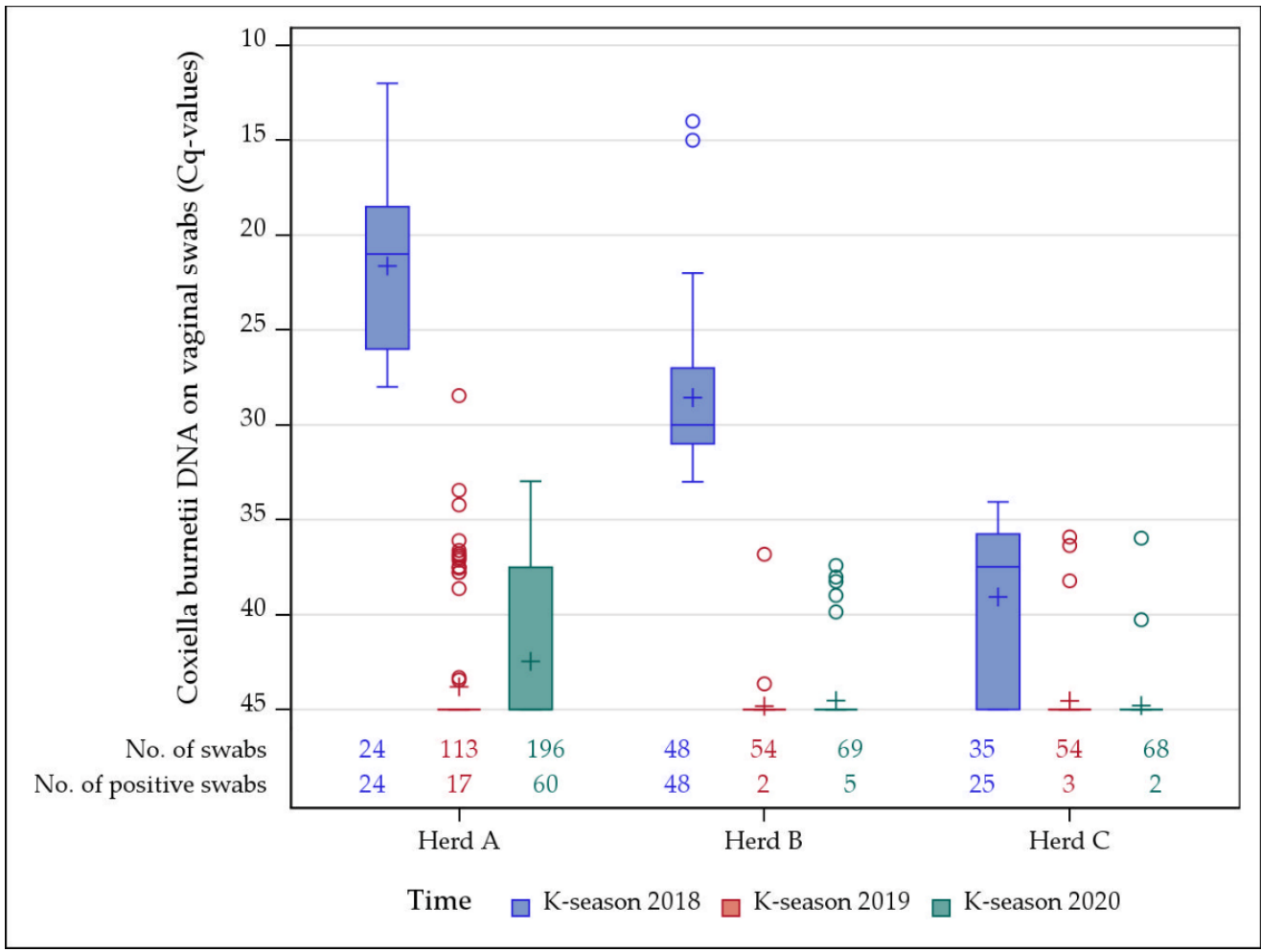

Figure 2. Coxiella burnetii shedding through vaginal route during three (2018-2020) kidding seasons (K-season) in three naturally C. burnetii infected dairy goat herds (A-C) analyzed by qPCR. All goat herds were vaccinated after C. burnetii had been diagnosed in 2018.

\subsection{Bulk Tank Milk}

After the initial detection of C. burnetii in the dairy goat herds, pathogen DNA was continuously detected in BTM samples for 9 and 16 months in herds A and B, respectively. In the following months, C. burnetii was identified irregularly in the BTM. In contrast, BTM specimens from goat herd $\mathrm{C}$ tested $\mathrm{C}$. burnetii positive at the beginning of the investigations and once again in August 2019 (Figure 3). In total, 50\% (16/32), 69\% (20/29), and 15\% $(4 / 26)$ positive BTM samples were detected in herds A, B, and C, respectively. 

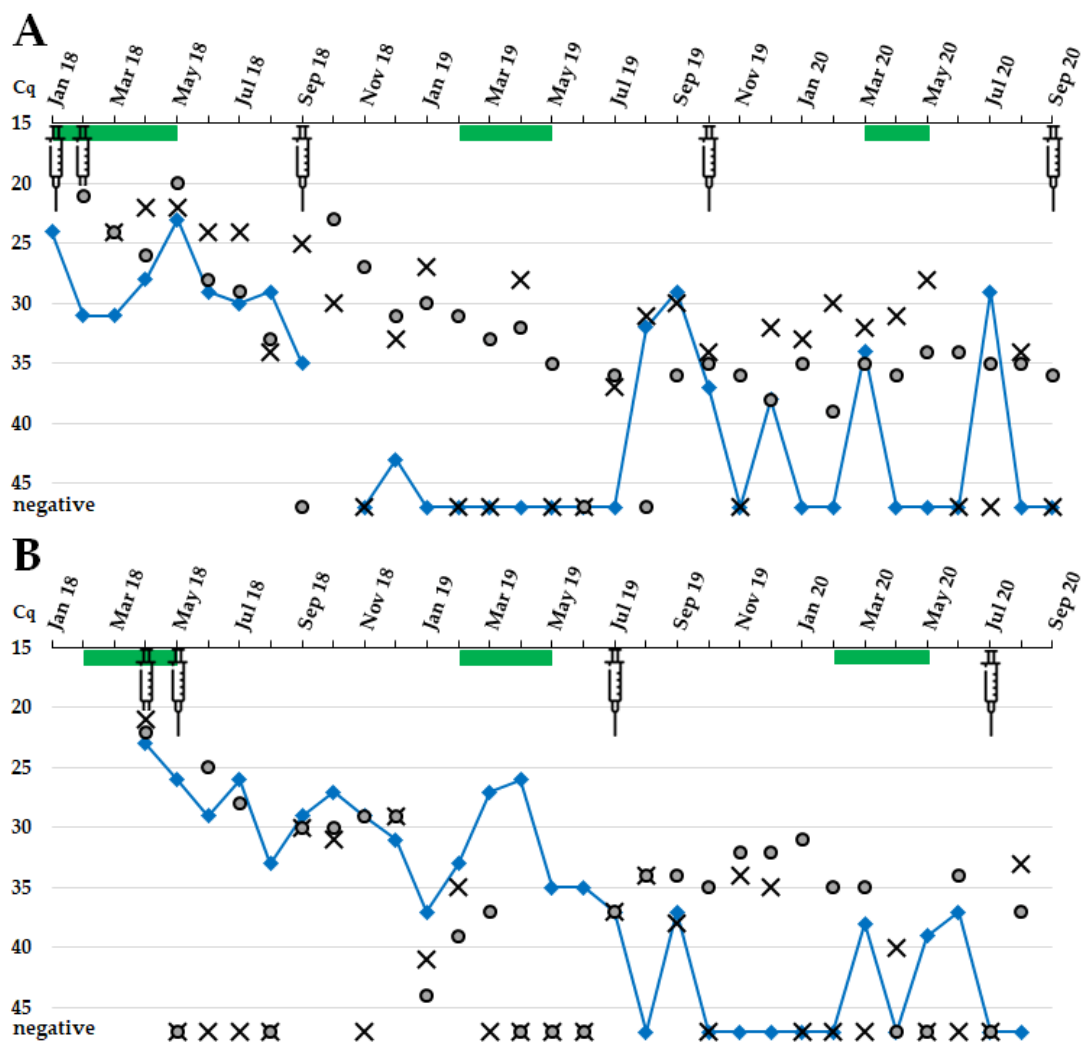

C
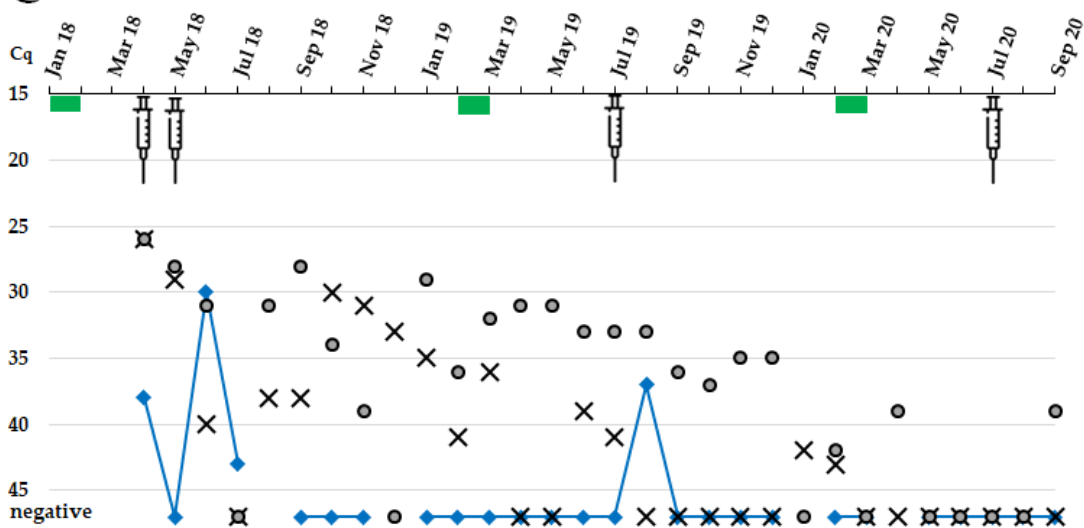

$\neg$-Bulk Tank Milk $\quad \times$ Barn Dust $\quad \circ$ Milking Parlor Dust

Figure 3. Coxiella burnetii detection by $\mathrm{qPCR}(\mathrm{Cq} \leq 45$ : positive result) in monthly collected bulk tank milk specimens $\bullet$ and dust samples from one windowsill of each barn $\mathbf{X}$ and from each milking parlor $\bullet$ in three naturally C. burnetii infected and vaccinated dairy goat herds (A-C). BTM samples were not always available at every sampling date from farm A and C. Green bar: kidding period syringe: vaccination; missing samples are not indicated.

\subsection{Dust from Barns and Milking Parlors}

Dust samples from the barns and milking parlors tested discontinuously C. burnetii positive on all three goat farms (Figure 3). On farm A, 71\% (22/31) of the barn dust samples tested C. burnetii positive, whereas specimens from farms B and C had $45 \%(13 / 29)$ and $50 \%(15 / 30)$ positive outcomes. The number of positive dust samples was higher from the milking parlors; $91 \%$ (A, 29/32), 72\% (B, 21/29), and 73\% (C, 22/30), respectively, compared to the windowsills from each of the barn. The $C$. burnetii burden from both sample locations showed an undulating development. 


\section{Discussion}

In the past, $C$. burnetii shedding small ruminants have caused small-scale human $Q$ fever outbreaks [2,12] in Germany, and one family member from farm A developed acute $\mathrm{Q}$ fever [44]. Without countermeasures, C. burnetii circulates in goat flocks for a certain time $[24,26,48]$. One animal can shed large amounts of the pathogen, leading to a high number of human $Q$ fever cases [12]. So-called 'super-shedders' were also detected in herds $A$ and $B$ in 2018. Therefore, we did not include control animals for vaccine evaluation due to public health reasons. Moreover, non-vaccinated animals within a positive herd increase the pathogen exposure and this may lead to underestimation vaccine efficiency $[30,49]$. In addition, such an approach does not support the overall objective to control $Q$ fever outbreaks. Information about fully vaccinated goat herds after a $Q$ fever outbreak is lacking, but is essential to help decision-makers of public health authorities to implement or lift restrictions. Therefore, our observations are in line with the One Health approach of improving the understanding of fully vaccinated goat herds after $Q$ fever outbreaks.

The examination of goat sera with phase-specific ELISAs revealed different $Q$ fever disease stages among all three dairy goat herds. According to the serological results with a dominance of IgG Ph II antibodies, the dairy goat herd A suffered from an acute Q fever outbreak. This is underlined by the high amount of $C$. burnetii excretion by half of the examined animals $(\mathrm{Cq} \leq 20)$ in January 2018. In herd $\mathrm{B}$, an ongoing infection was revealed with similar levels of both phase-specific IgGs, which coincides with the sampling time right after the kidding season, as the acute disease was already over. In contrast, the median of IgG Ph I antibodies was significantly higher compared to IgG Ph II in herd C, thus suggesting an infection in the past. This interpretation is supported by the fact that the samples were collected around two months after the main kidding season had been completed, and only $71 \%$ of vaginal swabs tested positive with a low C. burnetii amount $(\mathrm{Cq} \geq 34)$. Our findings are consistent with outcomes from naturally or experimentally infected goats [22-24]. Consequently, with the new phase-specific ELISAs, classification of C. burnetii positive goat herds into three different stages of infection was possible. Hence, the assays are helpful tools for evaluating the disease status in practice.

The reasons for the lack of control groups were already discussed in detail above. Therefore, we can only speculate about the effect of the vaccine on vaginal shedding. Nevertheless, taking into account that a considerable number of non-vaccinated goat herds still shed C. burnetii during the following kidding seasons [48,50], we suspect a positive effect of the vaccine to reduce the number of vaginal shedders and amount of pathogen excretion at subsequent parturitions. In all herds, the vaccine could not prevent shedding during the subsequent kidding periods, which is in line with previous findings [3,29-31]. Taken together, our clinical results indicate that vaccination for three years is insufficient to eliminate $C$. burnetii from infected dairy goat herds and emphasize the necessity for annual $Q$ fever vaccination for at least six years, as claimed by simulation models [26].

The irregular detection of $C$. burnetii DNA in BTM samples from herds A and B suggests intermittent milk shedders [51], which have so far only been confirmed in cattle [52,53] and not in goats. The risk of acquiring $Q$ fever by drinking raw milk or consuming raw milk products is low but cannot be fully excluded. In addition to C. burnetii, infected goats can also shed other zoonotic pathogens through milk, such as Toxoplasma gondii, Brucella melitensis, Listeria monocytogenes, and tick-borne encephalitis virus [54-57]. Due to the increasing popularity of drinking raw milk and new routes of sale for raw milk through vending machines and internet sale [58], it is necessary to raise the awareness of food-borne pathogens in raw milk and raw milk products.

Removing goats shedding C. burnetii intermittently in milk, led to negative BTM samples [51]. However, the 'test and cull' approach is cost-intensive and, thus, difficult to enforce in practice. Moreover, it will not result in eradicating $Q$ fever if applied as the exclusive control strategy [26]. In addition, vaccinating dairy goats with an inactivated $C$. burnetii phase I vaccine caused positive milk samples by qPCR up until nine days after vaccination [59]. Shedding of vaccine-antigen-DNA might be the reason for a single positive 
BTM sample (Cq 37) during 2019 in herd C, 31 days after the booster vaccination. Therefore, timing the vaccination and testing have to be considered if BTM samples are used for $Q$ fever surveillance.

The dust from the barns and milking parlors of all three dairy goat farms contained considerable amounts $(\mathrm{Cq}<30)$ of $C$. burnetii after the initial detection of the pathogen in 2018. The severe contamination is associated with the tremendous release of $C$. burnetii from aborting or kidding goats $[3,6,38]$. During the following months, the detection of $C$. burnetii from dust samples had an undulating development. Several factors affect the probability of detecting C. burnetii in animal facilities, such as sampling method and matrix, sampling location, used PCR method, activities during sampling, history of abortion, number of reproductive females, number of vaginal shedders, ventilation, and type of ruminant species $[3,38,40-42,45,60,61]$. This highlights the need for a standardized sampling method and performance to make the outcomes reliable and comparable.

Dust samples from the milking parlors were most frequently C. burnetii positive on all three dairy goat farms. Inhalable dust particles are raised during milking activity [45]. Hence, people performing daily milking are at a high risk of becoming infected with $C$. burnetii $[43,44]$. This should be taken into account in future risk assessments for farmers and farm workers. However, the detection of $C$. burnetii DNA from the surroundings provides no information about the viability of the pathogen. It is assumed that $C$. burnetii remains infectious in dust for up to two months after parturition [6]. Finally, the infectiousness of low C. burnetii DNA amounts in the environment remains doubtful and needs further clarification. Additionally, the barns and the milking parlors were contaminated for more than two years on all three farms. This is in line with observations from other studies on small ruminant farms $[3,40]$. Therefore, our findings point out the need for efficient sanitation protocols to decontaminate animal facilities in order to prevent pathogen spillovers to humans.

The authors are aware of the limitations of the present field study. Differences in stock density, interior design of barns and milking parlors, ventilation, management, and vaccination strategies, as well as C. burnetii infection status make a direct comparison among the three dairy goat herds difficult and limit the interpretation of our longitudinal study. In addition, it must be taken into account that $C$. burnetii strains on the three farms might contain different numbers of IS1111 elements [62]. Therefore, the results of the qPCR between the three farms are also not comparable. All these variations highlight the challenges in monitoring and controlling $Q$ fever outbreaks in veterinary practices.

\section{Conclusions}

Phase-specific serology enables the classification of the $Q$ fever disease status of goat herds and supports the identification of acute cases, which are a serious hazard for humans. The inactivated C. burnetii phase I vaccine did not prevent vaginal shedding in naturally pre-infected dairy goats at two subsequent kidding seasons, and underlines the need for vaccinating C. burnetii positive dairy goat herds for at least six years [26]. The long-term detection of $C$. burnetii in dust samples from milking parlors emphasizes the threat during milking activities. In the future, routine methods to determine the infectiousness of low C. burnetii amounts in dust samples are urgently needed to assess the risk of infection for humans and animals. In addition, the sensitivity of dust swabs to identify C. burnetii positive livestock has to be evaluated. Altogether, our observations highlight the use of phase-specific serology and the molecular analysis of various sampling matrices to monitor the status and shedding of $C$. burnetii in goat herds. The generated data are extremely helpful for $\mathrm{Q}$ fever risk assessments and supports the One Health approach.

Supplementary Materials: The following supporting information can be downloaded at: https: / / www.mdpi.com/article/10.3390/vetsci9030102/s1, Figure S1: Overview of blood/vaginal swab sampling, kidding seasons and vaccination schedules in three Coxiella burnetii positive dairy goat herds $(\mathrm{A}-\mathrm{C})$. 


\begin{abstract}
Author Contributions: Conceptualization, B.U.B. and M.G.; methodology, B.U.B., M.R. and M.G.; validation, B.U.B., C.S., M.R. and M.G.; formal analysis, B.U.B. and C.S.; investigation, B.U.B., C.S., T.L.H. and M.R.; resources, M.R. and M.G.; data curation, B.U.B., C.S. and T.L.H.; writing-original draft preparation, B.U.B.; writing-review and editing, C.S., M.R. and M.G.; visualization, B.U.B.; supervision, M.R. and M.G.; project administration, M.R. and M.G.; funding acquisition, M.R. and M.G. All authors have read and agreed to the published version of the manuscript.
\end{abstract}

Funding: This work was funded by the Federal Ministry of Education and Research (BMBF) under project number 01K11726B as part of the Research Network Zoonotic Infectious Diseases. This Open Access publication was funded by the Deutsche Forschungsgemeinschaft (DFG, German Research Foundation) within the program LE 824/10-1 “Open Access Publication Costs" and University of Veterinary Medicine Hannover, Foundation.

Institutional Review Board Statement: This field investigation did not require official or institutional ethical approval because all samples were taken during routine diagnostic procedures to improve animal health. This is in accordance with German animal welfare legislation and the EU Directive 2010/63/EU for animal experiments. All animals were handled in accordance with high ethical standards and national legislation.

Data Availability Statement: The data are available on request from the corresponding author.

Acknowledgments: Special thanks go to Annika Wolf, Melanie Stöter, Sabine Baumann, Hannah Habeck, Marie Keitel, Sina Korn, and Sandra Schöbel for their excellent technical support. Furthermore, we wish to thank Frances Sherwood-Brock for proofreading the English.

Conflicts of Interest: The authors declare no conflict of interest.

\title{
References
}

1. Mertens, K.; Gerlach, C.; Neubauer, H.; Henning, K. Q fever-An Update. Curr. Clin. Microbiol. Rep. 2017, 4, 61-70. [CrossRef]

2. Bauer, B.U.; Runge, M.; Campe, A.; Henning, K.; Mertens-Scholz, K.; Boden, K.; Sobotta, K.; Frangoulidis, D.; Knittler, M.R.; Matthiesen, S.; et al. Coxiella burnetii: A review focusing on infections in German sheep and goat flocks. Berl. Munch. Tierarztl. Wochenschr. 2020, 133, 184-200. [CrossRef]

3. Bauer, B.; Prüfer, L.; Walter, M.; Ganter, I.; Frangoulidis, D.; Runge, M.; Ganter, M. Comparison of Coxiella burnetii excretion between sheep and goats naturally infected with one cattle-associated genotype. Pathogens 2020, 9, 652. [CrossRef]

4. Rodolakis, A.; Berri, M.; Hechard, C.; Caudron, C.; Souriau, A.; Bodier, C.; Blanchard, B.; Camuset, P.; Devillechaise, P.; Natorp, J. Comparison of Coxiella burnetii shedding in milk of dairy bovine, caprine, and ovine herds. J. Dairy Sci. 2007, 90, 5352-5360. [CrossRef]

5. Palmer, N.; Kierstead, M.; Key, D.; Williams, J.; Peacock, M.; Vellend, H. Placentitis and abortion in goats and sheep in Ontario caused by Coxiella burnetii. Can. Vet. J. 1983, 24, 60-61.

6. Álvarez-Alonso, R.; Basterretxea, M.; Barandika, J.F.; Hurtado, A.; Idiazabal, J.; Jado, I.; Beraza, X.; Montes, M.; Liendo, P.; García-Pérez, A.L. A Q fever outbreak with a high rate of abortions in a dairy goat farm: Coxiella burnetii shedding, environmental contamination and viability. Appl. Environ. Microbiol. 2018, 84, e01650-18. [CrossRef]

7. Agerholm, J.S. Coxiella burnetii associated reproductive disorders in domestic animals-A critical review. Acta Vet. Scand. 2013, 55, 13. [CrossRef]

8. van den Brom, R.; Vellema, P. Q fever outbreaks in small ruminants and people in the Netherlands. Small Rumin. Res. 2009, 86, 74-79. [CrossRef]

9. $\quad$ Brooke, R.J.; Kretzschmar, M.E.; Mutters, N.T.; Teunis, P.F. Human dose response relation for airborne exposure to Coxiella burnetii. BMC Infect. Dis. 2013, 13, 488. [CrossRef]

10. Reedijk, M.; Van Leuken, J.P.G.; Van Der Hoek, W. Particulate matter strongly associated with human Q fever in The Netherlands: An ecological study. Epidemiol. Infect. 2013, 141, 2623-2633. [CrossRef]

11. van Roeden, S.E.; Holsboer, E.W.; Oosterheert, J.J.; van Kats, J.P.; van Beckhoven, J.; Hogema, B.M.; van Wijk, M.J. Seroprevalence of Coxiella burnetii antibodies and chronic Q fever among post-mortal and living donors of tissues and cells from 2010 to 2015 in The Netherlands. Eurosurveillance 2018, 23, 17-00384. [CrossRef]

12. Porten, K.; Rissland, J.; Tigges, A.; Broll, S.; Hopp, W.; Lunemann, M.; van Treeck, U.; Kimmig, P.; Brockmann, S.O.; WagnerWiening, C.; et al. A super-spreading ewe infects hundreds with $\mathrm{Q}$ fever at a farmers' market in Germany. BMC Infect. Dis. 2006, 6, 147. [CrossRef]

13. Signs, K.A.; Stobierski, M.G.; Gandhi, T.N. Q fever cluster among raw milk drinkers in Michigan, 2011. Clin. Infect. Dis. 2012, 55, 1387-1389. [CrossRef]

14. Raoult, D.; Marrie, T.J.; Mege, J.L. Natural history and pathophysiology of Q fever. Lancet Infect. Dis. 2005, 5, 219-226. [CrossRef]

15. Morroy, G.; Keijmel, S.P.; Delsing, C.E.; Bleijenberg, G.; Langendam, M.; Timen, A.; Bleeker-Rovers, C.P. Fatigue following acute Q-fever: A systematic literature review. PLoS ONE 2016, 11, e0155884. [CrossRef] 
16. Angelakis, E.; Raoult, D. Q fever. Vet. Micorbiol. 2010, 140, 297-309. [CrossRef]

17. Georgiev, M.; Alfonso, A.; Neubauer, H.; Needham, H.; Thiéry, R.; Rodolakis, A.; Roest, H.I.J.; Stärk, K.D.; Stegeman, J.A.; Vellema, P.; et al. Q fever in humans and farm animals in four European countries, 1982 to 2010. Eurosurveillance 2013, 18, 20407. [CrossRef]

18. Anderson, A.D.; Kruszon-Moran, D.; Loftis, A.D.; McQuillan, G.; Nicholson, W.L.; Priestley, R.A.; Candee, A.J.; Patterson, N.E.; Massung, R.F. Seroprevalence of $Q$ fever in the United States, 2003-2004. Am. J. Trop. Med. Hyg. 2009, 81, 691-694. [CrossRef]

19. Tozer, S.; Lambert, S.; Sloots, T.; Nissen, M. Q fever seroprevalence in metropolitan samples is similar to rural/remote samples in Queensland, Australia. Eur. J. Clin. Microbiol. Infect. Dis. 2011, 30, 1287. [CrossRef]

20. Stoker, M.G.P.; Fiset, P. Phase variation of the Nine Mile and other strains of Rickettsia Burneti. Can. J. Microbiol. 1956, 2, 310-321. [CrossRef]

21. Williams, J.; Johnston, M.; Peacock, M.; Thomas, L.; Stewart, S.; Portis, J. Monoclonal antibodies distinguish phase variants of Coxiella burnetii. Infect. Immun. 1984, 43, 421-428. [CrossRef] [PubMed]

22. Roest, H.; Post, J.; van Gelderen, B.; van Zijderveld, F.G.; Rebel, J.M. Q fever in pregnant goats: Humoral and cellular immune responses. Vet. Res. 2013, 44, 67. [CrossRef] [PubMed]

23. Sting, R.; Molz, K.; Philipp, W.; Bothe, F.; Runge, M.; Ganter, M. Quantitative real-time PCR and phase specific serology are mutually supportive in Q fever diagnostics in goats. Vet. Microbiol. 2013, 167, 600-608. [CrossRef] [PubMed]

24. Hatchette, T.; Campbell, N.; Hudson, R.; Raoult, D.; Marrie, T.J. Natural history of Q fever in goats. Vector Borne Zoonotic Dis. 2003, 3, 11-15. [CrossRef] [PubMed]

25. Muleme, M.; Stenos, J.; Vincent, G.; Wilks, C.R.; Devlin, J.M.; Campbell, A.; Cameron, A.; Stevenson, M.A.; Graves, S.; Firestone, S.M. Peripartum dynamics of Coxiella burnetii infections in intensively managed dairy goats associated with a $Q$ fever outbreak in Australia. Prev. Vet. Med. 2017, 139, 58-66. [CrossRef]

26. Bontje, D.; Backer, J.; Hogerwerf, L.; Roest, H.; van Roermund, H. Analysis of Q fever in Dutch dairy goat herds and assessment of control measures by means of a transmission model. Prev. Vet. Med. 2016, 123, 71-89. [CrossRef]

27. Canevari, J.T.; Firestone, S.M.; Vincent, G.; Campbell, A.; Tan, T.; Muleme, M.; Cameron, A.W.N.; Stevenson, M.A. The prevalence of Coxiella burnetii shedding in dairy goats at the time of parturition in an endemically infected enterprise and associated milk yield losses. BMC Vet. Res. 2018, 14, 353. [CrossRef]

28. Achard, D.; Rodolakis, A. Q fever vaccination in ruminants: A critical review. In The Principles and Practice of $Q$ Fever; Caetano Simoes, J.C., Ferreira, A.S., de Silva, G.J., Eds.; Nova Science Publishers Inc.: New York, NY, USA, 2017; pp. 367-389.

29. Arricau-Bouvery, N.; Souriau, A.; Bodier, C.; Dufour, P.; Rousset, E.; Rodolakis, A. Effect of vaccination with phase I and phase II Coxiella burnetii vaccines in pregnant goats. Vaccine 2005, 23, 4392-4402. [CrossRef]

30. De Cremoux, R.; Rousset, E.; Touratier, A.; Audusseau, G.; Nicollet, P.; Ribaud, D.; David, V.; Le Pape, M. Assessment of vaccination by a phase I Coxiella burnetii-inactivated vaccine in goat herds in clinical $\mathrm{Q}$ fever situation. FEMS Immunol. Med. Microbiol. 2012, 64, 104-106. [CrossRef]

31. Rousset, E.; Durand, B.; Champion, J.L.; Prigent, M.; Dufour, P.; Forfait, C.; Marois, M.; Gasnier, T.; Duquesne, V.; Thiery, R.; et al. Efficiency of a phase 1 vaccine for the reduction of vaginal Coxiella burnetii shedding in a clinically affected goat herd. Clin. Microbiol. Infect. 2009, 15 (Suppl. S2), 188-189. [CrossRef]

32. Hogerwerf, L.; van den Brom, R.; Roest, H.I.J.; Bouma, A.; Vellema, P.; Pieterse, M.; Dercksen, D.P.; Nielen, M. Reduction of Coxiella burnetii prevalence by vaccination of goats and sheep, The Netherlands. Emerg. Infect. Dis. 2011, 17, 379-386. [CrossRef] [PubMed]

33. van den Brom, R.; Santman-Berends, I.; Luttikholt, S.; Moll, L.; Van Engelen, E.; Vellema, P. Bulk tank milk surveillance as a measure to detect Coxiella burnetii shedding dairy goat herds in the Netherlands between 2009 and 2014. J. Dairy Sci. 2015, 98, 3814-3825. [CrossRef] [PubMed]

34. van den Brom, R.; van Engelen, E.; Luttikholt, S.; Moll, L.; van Maanen, K.; Vellema, P. Coxiella burnetii in bulk tank milk samples from dairy goat and dairy sheep farms in The Netherlands in 2008. Vet. Rec. 2012, 170, 310. [CrossRef] [PubMed]

35. Jansen, W.; Cargnel, M.; Boarbi, S.; Mertens, I.; Van Esbroeck, M.; Fretin, D.; Mori, M. Belgian bulk tank milk surveillance program reveals the impact of a continuous vaccination protocol for small ruminants against Coxiella burnetii. Transbound. Emerg. Dis. 2021, 1-12. [CrossRef]

36. Jodełko, A.; Szymańska-Czerwińska, M.; Rola, J.G.; Niemczuk, K. Molecular detection of Coxiella burnetii in small ruminants and genotyping of specimens collected from goats in Poland. BMC Vet. Res. 2021, 17, 341. [CrossRef]

37. Khalili, M.; Diali, H.G.; Mirza, H.N.; Mosavi, S.M. Detection of Coxiella burnetii by PCR in bulk tank milk samples from dairy caprine herds in southeast of Iran. Asian Pac. J. Trop. Dis. 2015, 5, 119-122. [CrossRef]

38. Carrié, P.; Barry, S.; Rousset, E.; de Crémoux, R.; Sala, C.; Calavas, D.; Perrin, J.B.; Bronner, A.; Gasqui, P.; Gilot-Fromont, E.; et al. Swab cloths as a tool for revealing environmental contamination by $Q$ fever in ruminant farms. Transbound. Emerg. Dis. 2019, 66, 1202-1209. [CrossRef]

39. Zendoia, I.I.; Barandika, J.F.; Hurtado, A.; López, C.M.; Alonso, E.; Beraza, X.; Ocabo, B.; García-Pérez, A.L. Analysis of environmental dust in goat and sheep farms to assess Coxiella burnetii infection in a $\mathrm{Q}$ fever endemic area: Geographical distribution, relationship with human cases and genotypes. Zoonoses Public Health 2021, 68, 666-676. [CrossRef]

40. Álvarez-Alonso, R.; Zendoia, I.I.; Barandika, J.F.; Jado, I.; Hurtado, A.; López, C.M.; García-Pérez, A.L. Monitoring Coxiella burnetii infection in naturally infected dairy sheep flocks throughout four lambing seasons and investigation of viable bacteria. Front. Vet. Sci. 2020, 7, 352. [CrossRef] 
41. Joulié, A.; Laroucau, K.; Bailly, X.; Prigent, M.; Gasqui, P.; Lepetitcolin, E.; Blanchard, B.; Rousset, E.; Sidi-Boumedine, K.; Jourdain, E. Circulation of Coxiella burnetii in a naturally infected flock of dairy sheep: Shedding dynamics, environmental contamination, and genotype diversity. Appl. Environ. Microbiol. 2015, 81, 7253-7260. [CrossRef]

42. de Bruin, A.; de Groot, A.; de Heer, L.; Bok, J.; Hamans, M.; van Rotterdam, B.; Wielinga, P.; Janse, I. Detection of Coxiella burnetii in complex matrices by using multiplex qPCR during a major $\mathrm{Q}$ fever outbreak in the Netherlands. Appl. Environ. Microbiol. 2011, 77, 6516-6523. [CrossRef] [PubMed]

43. Schimmer, B.; Lenferink, A.; Schneeberger, P.; Aangenend, H.; Vellema, P.; Hautvast, J.; van Duynhoven, Y. Seroprevalence and risk factors for Coxiella burnetii (Q fever) seropositivity in dairy goat farmers' households in The Netherlands, 2009-2010. PLoS ONE 2012, 7, e42364. [CrossRef]

44. Bauer, B.U.; Knittler, M.R.; Herms, T.L.; Frangoulidis, D.; Matthiesen, S.; Tappe, D.; Runge, M.; Ganter, M. Multispecies Q fever outbreak in a mixed dairy goat and cattle farm based on a new bovine-associated genotype of Coxiella burnetii. Vet. Sci. 2021, 8 , 252. [CrossRef] [PubMed]

45. Hogerwerf, L.; Borlée, F.; Still, K.; Heederik, D.; van Rotterdam, B.; de Bruin, A.; Nielen, M.; Wouters, I.M. Detection of Coxiella burnetii DNA in inhalable airborne dust samples from goat farms after mandatory culling. Appl. Environ. Microbiol. 2012, 78, 5410-5412. [CrossRef]

46. Bauer, B.U.; Knittler, M.R.; Prüfer, T.L.; Wolf, A.; Matthiesen, S.; Runge, M.; Ganter, M. Humoral immune response to Q fever vaccination of three sheep flocks naturally pre-infected with Coxiella burnetii. Vaccine 2021, 39, 1499-1507. [CrossRef] [PubMed]

47. Frangoulidis, D.; Walter, M.C.; Antwerpben, M.; Zimmermann, P.; Janowetz, B.; Alex, M.; Böttcher, J.; Henning, K.; Hilbert, A.; Ganter, M.; et al. Molecular analysis of Coxiella burnetii in Germany reveals evolution of unique clonal clusters. Int. J. Med. Microbiol. 2014, 304, 868-876. [CrossRef] [PubMed]

48. Berri, M.; Rousset, E.; Champion, J.; Russo, P.; Rodolakis, A. Goats may experience reproductive failures and shed Coxiella burnetii at two successive parturitions after a $Q$ fever infection. Res. Vet. Sci. 2007, 83, 47-52. [CrossRef]

49. Guatteo, R.; Seegers, H.; Joly, A.; Beaudeau, F. Prevention of Coxiella burnetii shedding in infected dairy herds using a phase I C. burnetii inactivated vaccine. Vaccine 2008, 26, 4320-4328. [CrossRef]

50. de Cremoux, R.; Rousset, E.; Touratier, A.; Audusseau, G.; Nicollet, P.; Ribaud, D.; David, V.; Le Pape, M. Coxiella burnetii vaginal shedding and antibody responses in dairy goat herds in a context of clinical $Q$ fever outbreaks. FEMS Immunol. Med. Microbiol. 2012, 64, 120-122. [CrossRef]

51. van den Brom, R.; van Engelen, E.; Vos, J.; Luttikholt, S.J.M.; Moll, L.; Roest, H.I.J.; van der Heijden, H.M.J.F.; Vellema, P. Detection of Coxiella burnetii in the bulk tank milk from a farm with vaccinated goats, by using a specific PCR technique. Small Rumin. Res. 2013, 110, 150-154. [CrossRef]

52. Lucchese, L.; Capello, K.; Barberio, A.; Zuliani, F.; Stegeman, A.; Ceglie, L.; Guerrini, E.; Marangon, S.; Natale, A. IFAT and ELISA phase I/phase II as tools for the identification of Q fever chronic milk shedders in cattle. Vet. Microbiol. 2015, 179, 102-108. [CrossRef]

53. Böttcher, J.; Frangoulidis, D.; Schumacher, M.; Janowetz, B.; Gangl, A.; Alex, M. The impact of Q fever-phase-specific milk serology for the diagnosis of puerperal and chronic milk shedding of C. burnetii in dairy cows. Berl. Munch. Tierarztl. Wochenschr. 2013, 126, 427-435. [CrossRef] [PubMed]

54. Dubey, J.P.; Verma, S.K.; Ferreira, L.R.; Oliveira, S.; Cassinelli, A.B.; Ying, Y.; Kwok, O.C.H.; Tuo, W.; Chiesa, O.A.; Jones, J.L. Detection and survival of Toxoplasma gondii in milk and cheese from experimentally infected goats. J. Food Prot. 2014, 77, 1747-1753. [CrossRef] [PubMed]

55. Addis, M.F.; Cubeddu, T.; Pilicchi, Y.; Rocca, S.; Piccinini, R. Chronic intramammary infection by Listeria monocytogenes in a clinically healthy goat-A case report. BMC Vet. Res. 2019, 15, 229. [CrossRef] [PubMed]

56. Higgins, J.L.; Gonzalez-Juarrero, M.; Bowen, R.A. Evaluation of shedding, tissue burdens, and humoral immune response in goats after experimental challenge with the virulent Brucella melitensis strain 16M and the reduced virulence vaccine strain Rev. 1 PLoS ONE 2017, 12, e0185823. [CrossRef] [PubMed]

57. Ilic, M.; Barbic, L.; Bogdanic, M.; Tabain, I.; Savic, V.; Kosanovic Licina, M.L.; Kaic, B.; Jungic, A.; Vucelja, M.; Angelov, V.; et al. Tick-borne encephalitis outbreak following raw goat milk consumption in a new micro-location, Croatia, June 2019. Ticks Tick Borne Dis. 2020, 11, 101513. [CrossRef]

58. EFSA Panel on Biological Hazards. Scientific opinion on the public health risks related to the consumption of raw drinking milk. EFSA J. 2015, 13, 3940. [CrossRef]

59. Hermans, M.H.; Huijsmans, C.R.; Schellekens, J.J.; Savelkoul, P.H.; Wever, P.C. Coxiella burnetii DNA in goat milk after vaccination with Coxevac ${ }^{\circledR}$. Vaccine 2011, 29, 2653-2656. [CrossRef]

60. Kersh, G.J.; Fitzpatrick, K.A.; Self, J.S.; Priestley, R.A.; Kelly, A.J.; Lash, R.R.; Marsden-Haug, N.; Nett, R.J.; Bjork, A.; Massung, R.F.; et al. Presence and persistence of Coxiella burnetii in the environment of goat farms associated with a $\mathrm{Q}$ fever outbreak. Appl. Environ. Microbiol. 2013, 79, 1697-1703. [CrossRef]

61. Astobiza, I.; Barandika, J.F.; Ruiz-Fons, F.; Hurtado, A.; Povedano, I.; Juste, R.A.; García-Pérez, A.L. Coxiella burnetii shedding and environmental contamination at lambing in two highly naturally-infected dairy sheep flocks after vaccination. Res. Vet. Sci. 2011, 91, e58-e63. [CrossRef]

62. Klee, S.R.; Tyczka, J.; Ellerbrok, H.; Franz, T.; Linke, S.; Baljer, G.; Appel, B. Highly sensitive real-time PCR for specific detection and quantification of Coxiella burnetii. BMC Microbiol. 2006, 6, 2. [CrossRef] 